\title{
Phosphite and phosphate in the accumulation and translocation of nutrients in common bean ${ }^{1}$
}

\author{
Josinaldo Lopes Araujo 2 , Fabrício William de Ávila³, Valdemar Faquin ${ }^{4}$
}

\section{ABSTRACT}

Although used as an additional nutritional source of phosphorus in agriculture, little is known about the effects of phosphites on plants. In order to evaluate the influence of phosphite and phosphate on the accumulation and translocation of phosphorus and cationic nutrients, in common bean, three experiments were conducted. In the first experiment, five concentrations $\left(0.5 \mathrm{mg} \mathrm{L}^{-1}, 10 \mathrm{mg} \mathrm{L}^{-1}, 20 \mathrm{mg} \mathrm{L}^{-1}, 30 \mathrm{mg} \mathrm{L}^{-1}\right.$ and $\left.60 \mathrm{mg} \mathrm{L}^{-1}\right)$ were studied in a nutrient solution combined with two forms of phosphorus [phosphate (Pi) and phosphite (Phi)]. In the second one, five Phi/Pi ratios were tested $(0 / 100,25 / 75,50 / 50$, $75 / 25$ and $100 / 0)$. In the third experiment, two phosphate levels ( $1.5 \mathrm{mg} \mathrm{L}^{-1}=$ limiting and $20 \mathrm{mg} \mathrm{L}^{-1}=$ adequate phosphorus) and three treatments related to foliar fertilization $\left(\mathrm{KH}_{2} \mathrm{PO}_{3}, \mathrm{KH}_{2} \mathrm{PO}_{4}\right.$ and $\mathrm{KCl}$ solutions) were combined in the nutrient solution. Phosphite via roots caused a decrease in the accumulation of phosphorus and cationic nutrients, under phosphate deficiency. $\mathrm{P}$-Phi decreased the $\mathrm{Zn} / \mathrm{P}$ ratio more than $\mathrm{P}-\mathrm{Pi}$, increased the translocation of $\mathrm{P}$ and decreased the translocation of Fe. The foliar supply of P-Phi did not affect the phosphorus nutrition of bean plants or the translocation of nutrients, but decreased the accumulation of $\mathrm{K}, \mathrm{Ca}, \mathrm{Mg}, \mathrm{Fe}$ and $\mathrm{Mn}$. Foliar P-Pi, at an adequate $\mathrm{P}$ supply in the nutrient solution, increased the accumulation of this nutrient.

KEYWORDS: Phaseolus vulgaris; phosphorus nutrition; cationic nutrients.

\section{INTRODUCTION}

Among the products registered by the Brazilian Ministry of Agriculture, Livestock and Supply and marketed as foliar or soil fertilizers, phosphite-based formulations have been increasingly used in recent years (Araujo 2008). In Brazil, phosphites $\left(\mathrm{H}_{2} \mathrm{PO}_{3}^{-}\right.$, $\mathrm{HPO}_{3}^{-2}$ ) are recommended mainly as a source of phosphorus and sometimes as fungicides (Schröetter

\section{RESUMO}

Fosfito e fosfato no acúmulo e translocação de nutrientes em feijoeiro

Apesar de ser utilizado como fonte nutricional suplementar de fósforo, na agricultura, pouco se conhece sobre os efeitos dos fosfitos nas plantas. Objetivou-se avaliar a influência do fosfito e do fosfato sobre o acúmulo e a translocação de fósforo e nutrientes cationicos, em feijoeiro comum. Para isso, foram instalados três experimentos. No primeiro, foram estudadas cinco concentrações $\left(0,5 \mathrm{mg} \mathrm{L}^{-1} ; 10 \mathrm{mg} \mathrm{L}^{-1} ; 20 \mathrm{mg} \mathrm{L}^{-1} ; 30 \mathrm{mg} \mathrm{L}^{-1}\right.$; $\left.60 \mathrm{mg} \mathrm{L}^{-1}\right)$, combinadas com duas formas de fósforo [fosfato (Pi) e fosfito (Phi)], em solução nutritiva. No segundo experimento, foram testadas cinco proporções de Phi/Pi (0/100, 25/75, 50/50, $75 / 25$ e 100/0). No terceiro, foram combinados dois níveis de fosfato, na solução nutritiva $\left(1,5 \mathrm{mg} \mathrm{L}^{-1}=\right.$ limitante e $20 \mathrm{mg} \mathrm{L}^{-1}=$ fósforo adequado), e três tratamentos referentes à adubação foliar (soluções de $\mathrm{KH}_{2} \mathrm{PO}_{3}, \mathrm{KH}_{2} \mathrm{PO}_{4}$ e $\mathrm{KCl}$ ). Sob carência de fosfato, o fosfito via radicular causou diminuição no acúmulo de fósforo e nutrientes catiônicos. O P-Phi diminuiu a razão $\mathrm{Zn} / \mathrm{P}$ mais que o P-Pi, aumentou a translocação de $\mathrm{P}$ e diminuiu a de Fe. O fornecimento de P-Phi via foliar não afetou a nutrição fosfatada do feijoeiro e nem a translocação de nutrientes, mas diminuiu o acúmulo de K, Ca, Mg, Fe e Mn. O P-Pi via foliar, sob suprimento adequado de $\mathrm{P}$ na solução, elevou o acúmulo deste nutriente.

PALAVRAS-CHAVE: Phaseolus vulgaris; nutrição fosfatada; nutrientes catiônicos.

et al. 2006, Moor et al. 2009, Gómez-Merino \& Trejo-Téllez 2015).

Many beneficial effects of phosphites on crops have been reported in some studies. Tambascio et al. (2014) observed that phosphite provided an increase in the emergence of tubers, leaf area and mycorrhizal colonization in potatoes. Estrada-Ortiz et al. (2013) reported that the use of phosphite in the nutrient solution increased the concentration of free amino

1. Manuscript received in Apr./2016 and accepted for publication in Oct./2016 (http://dx.doi.org/10.1590/1983-40632016v4640810).

2. Universidade Federal de Campina Grande, Centro de Ciências e Tecnologia Agroalimentar, Pombal, PB, Brazil. E-mail: josinaldo@ccta.ufcg.edu.br.

3. Universidade Estadual do Centro-Oeste, Departamento de Agronomia, Guarapuava, PR, Brazil. E-mail: avilafw@yahoo.com.br.

4. Universidade Federal de Lavras, Departamento de Ciência do Solo, Lavras, MG, Brasil. E-mail: vafaquin@dcs.ufla.br. 
acids, protein and sugar contents and anthocyanins in strawberries. Bertsch et al. (2009) found that phosphite, supplied with phosphate in the nutrient solution and with a proportion of $50 \%$ of each form of $\mathrm{P}$, provided an increase in the production of dry mass, leaf area and accumulation of $\mathrm{P}$ in lettuce, tomato and banana. Rickard (2000) reported that phosphite increased sugar contents and soluble solids in pears and increased the firmness and the intensity of red in raspberries.

In relation to the effects of phosphite on plant nutrition, except for phosphorus, there is little scientific information available (Ávila et al. 2012). For phosphorus, the results obtained by several authors show that phosphite does not replace phosphates $\left(\mathrm{H}_{2} \mathrm{PO}_{4}^{-}, \mathrm{HPO}_{4}{ }^{2-}\right.$ and $\left.\mathrm{PO}_{4}{ }^{3-}\right)$ in the plant metabolism (Araujo 2008, Thao \& Yamakawa 2009, Moor et al. 2009, Ávila et al. 2011 and 2012, Araújo et al. 2013 and 2014). This is because phosphite has one less oxygen atom, which is substituted by a hydrogen atom, if compared to phosphate. This change in the molecular structure results in changes in the metabolism of phosphorus by plants, causing physiological disorders (Gómez-Merino \& TrejoTéllez 2015). One aspect little explored in such studies is the effect of phosphite on the accumulation and transport of nutrients and on the $\mathrm{Zn} / \mathrm{P}$ ratio. Araújo et al. (2014) observed that, in the absence of phosphate, or when the proportions of phosphite were higher than the proportions of phosphate in the nutrient solution, there was a drastic reduction in bean growth, both in shoots and roots.

Considering the influence of phosphite on the plant metabolism, it is presumed that phosphite interferes not only with the phosphorus nutrition of bean plants, but also with the accumulation and translocation of other nutrients. In this sense, Ávila et al. (2012) observed that the foliar application of phosphite increased $\mathrm{K}, \mathrm{Ca}, \mathrm{Mg}, \mathrm{Cu}, \mathrm{Mn}$ and Fe contents in common bean grown in soil with a low phosphate availability. However, this increase was attributed to the concentration effect, because phosphite promoted a decrease in the production of dry mass. On the other hand, Orbović et al. (2008) found no consistent effects of phosphite on the mineral nutrition of citrus sweet orange seedlings (Citrus sinensis L. Osbeck). Araújo et al. (2013) observed that $\mathrm{P}$ provided in the form of phosphite in the nutrient solution was translocated at a higher quantity to shoots of bean plants, if compared to phosphate. This was probably due to the smaller size of the phosphite ion. In addition, the authors found, after 10 days of cultivation, typical iron deficiency symptoms in young leaves of bean plants under phosphite phytotoxicity.

The present study aimed at evaluating the effects of phosphite, applied via roots and leaves, on the accumulation and translocation of phosphorus and cationic nutrients in common bean grown in a nutrient solution.

\section{MATERIAL AND METHODS}

Three experiments were conducted in a nutrient solution, at a greenhouse of the Universidade Federal de Lavras, in Lavras, Minas Gerais State, Brazil, from January to March 2008, using common bean (Phaseolus vulgaris L. cv. BRS Radiante). This cultivar was chosen because of its short cycle, defined and upright growth, and also because it is well accepted by consumers.

Common bean seeds were germinated in standard vermiculite, in expanded polystyrene trays. Three days after emergence, uniform plants were chosen and transferred to pots containing $3 \mathrm{~L}$ of the nutrient solution described in Araújo et al. (2013), with $50 \%$ of its original concentration. The nutrient solution composition was adjusted according to the treatments with phosphorus levels and forms. After 5 days of cultivation, the concentration of the nutrient solution was increased to $100 \%$. This concentration was kept until the end of the experiment. The initial volume of solution in the pots was daily corrected with deionized water and replaced every 5 days. The $\mathrm{pH}$ was kept between 5.5 and 6.0 , by adding $\mathrm{NaOH}$ or $\mathrm{HCl}$ at $1.0 \mathrm{~mol} \mathrm{~L}^{-1}$. In the three experiments, potassium phosphite $\left(\mathrm{KH}_{2} \mathrm{PO}_{3}\right)$ was used. It was obtained by a neutralization reaction between phosphorous acid p.a. $\left(\mathrm{H}_{3} \mathrm{PO}_{3}\right)$ with potassium hydroxide p.a. $(\mathrm{KOH})$. Before this procedure, the phosphorous acid was standardized with sodium hydroxide. As a phosphate source, the monobasic potassium phosphate p.a. $\left(\mathrm{KH}_{2} \mathrm{PO}_{4}\right)$ was used.

In the three experiments, the design was completely randomized. The first and the second experiments consisted of providing phosphite via roots. In the first experiment, a $5 \times 2$ factorial design, with five concentrations $\left(0.5 \mathrm{mg} \mathrm{L}^{-1}, 10 \mathrm{mg} \mathrm{L}^{-1}\right.$, $20 \mathrm{mg} \mathrm{L}^{-1}, 30 \mathrm{mg} \mathrm{L}^{-1}$ and $60 \mathrm{mg} \mathrm{L}^{-1}$ ) and two forms of $\mathrm{P}$ [phosphate (Pi) and phosphite (Phi)], with four 
replications, was used. Each experimental unit had three plants per pot. The concentration of $0.5 \mathrm{mg} \mathrm{L}^{-1}$ of $\mathrm{P}$ intended to provide a minimum amount of phosphorus capable of producing plant material for the evaluations. The other concentrations were established based on the recommended dose of $\mathrm{P}$ for common bean in nutrient solution, as described by Araújo et al. (2013). In the second experiment, the aim was to verify the possibility of phosphate being replaced by phosphite. Therefore, the treatments consisted of five Phi/Pi ratios (0/100, 25/75, 50/50, 75/25 and 100/0) and five replications. Each replication was represented by one pot with two plants.

For the third experiment, the treatments were arranged in a $2 \times 3$ factorial design, combining two levels of phosphate in the nutrient solution [representing limiting levels $\left(1.5 \mathrm{mg} \mathrm{L}^{-1}\right)$ and adequate levels $\left.\left(20 \mathrm{mg} \mathrm{L}^{-1}\right)\right]$ with three solutions, for foliar application $\left(\mathrm{KH}_{2} \mathrm{PO}_{3}, \mathrm{KH}_{2} \mathrm{PO}_{4}\right.$ and $\mathrm{KCl}$ as a control). There were six replicates. Each experimental unit was represented by two plants per pot.

The $\mathrm{P}\left(\mathrm{KH}_{2} \mathrm{PO}_{3}\right.$ and $\left.\mathrm{KH}_{2} \mathrm{PO}_{4}\right)$ and $\mathrm{KCl}$ solutions were applied at $40 \mathrm{mmol} \mathrm{L}^{-1}$ (Araújo et al. 2013). Two applications were conducted: one in the emergence of the first trifoliate (V3 stage) and another during pre-flowering ( $\mathrm{R} 5$ stage). The $\mathrm{P}$ concentration used was equivalent to a dose of approximately $3 \mathrm{~L}$ of commercial potassium phosphite containing $131 \mathrm{~g} \mathrm{~L}^{-1}$ of $\mathrm{P}$ as phosphite for $400 \mathrm{~L}$ of solution, which is usually recommended for crops such as bean. To optimize the effect of foliar applications, the adhesive spreader ADESIL $^{\circledR}$ (Agripec) was added to all solutions, at a dose of $0.2 \mathrm{~mL} \mathrm{~L}^{-1}$.

In all experiments, plants were harvested at flowering (32 days after the installation of the experiment). The collected material was divided into roots and shoots, to obtain the dry mass $\left(60-65^{\circ} \mathrm{C}\right)$ of these tissues. Then, each part was individually milled in a Wiley mill, in order to determine the levels of $\mathrm{P}, \mathrm{K}, \mathrm{Ca}, \mathrm{Mg}, \mathrm{Fe}, \mathrm{Mn}$ and $\mathrm{Cu}$, and mass, root dry matter and nutrient content data, total accumulation of each nutrient in the plant and the respective translocation index for shoots [translocation $=($ nutrient accumulation in shoots)/(total accumulation $) \times 100$ ] were calculated. Considering the negative interaction which generally occurs between $\mathrm{Zn}$ and $\mathrm{P}$, when the form of $P$ is phosphate (Mai 2011), the $\mathrm{Zn} / \mathrm{P}$ and $\mathrm{Znt} / \mathrm{Pt}$ ratios were obtained considering the foliar $\mathrm{Zn}$ and $\mathrm{P}$ contents and the total accumulation of $\mathrm{Zn}(\mathrm{Znt})$ and $\mathrm{P}(\mathrm{Pt})$, respectively.
The statistical analysis consisted of analysis of variance, regression analysis and Tukey test, when appropriate, at $5 \%$, using the software Saeg, version 9.1. In the experiment with proportions of phosphite and phosphate in the nutrient solution, a polynomial regression analysis was conducted, considering the proportions of phosphite as the independent variable.

\section{RESULTS AND DISCUSSION}

The total dry mass of the plants was significantly influenced by the concentrations and forms of phosphorus (P) in the nutrient solution (Figure 1). It was observed that providing $\mathrm{P}$ exclusively in the form of phosphite (Phi) decreases the dry mass of common bean by about $95 \%$. One possible explanation for the phytotoxicity could be the fact that phosphite, when phosphate is deficient, increases the concentration of poly and pyrophosphates and inhibits several enzymes of the glycolysis and pentose phosphate pathway, thus interfering with the metabolism of $\mathrm{P}$ (Varadarajan et al. 2002).

There was interaction between concentrations and forms of $\mathrm{P}$ for the variables evaluated, except for the translocation rates of $\mathrm{K}, \mathrm{Ca}, \mathrm{Mn}, \mathrm{Zn}$ and $\mathrm{Cu}$. When phosphite (Phi) was the exclusive source of phosphorus $(\mathrm{P})$, the accumulation of $\mathrm{P}$ and cationic nutrients were lower, if compared to the application of phosphate as a source of P (Figure 2). Since the accumulation of a given element by the plant depends on its concentration in tissues and the produced dry matter, this effect was probably due

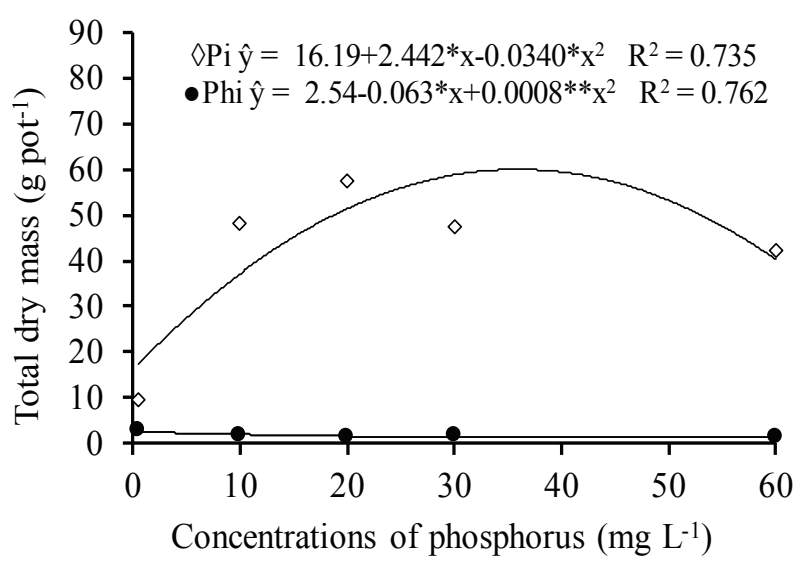

Figure 1. Total dry mass of common bean grown in nutrient solution under concentrations of phosphate (Pi) and phosphite (Phi). $* *$ and $*$ : significant at $1 \%$ and $5 \%$ by the F test, respectively. 

\[ \text { (a) } \hat{y}=-0.4012+18.214 * x-0.1866 * * x^{2} ; R^{2}=0.932 \]
$\bullet P h i \hat{y}=\bar{y}=14.961$

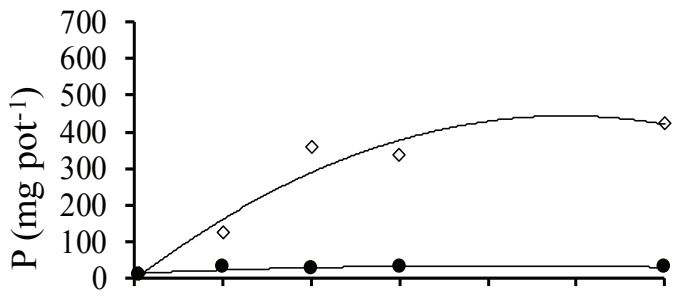

(c) $\diamond$ Pi $\hat{y}=276.96+36.442 * * x-0.5106 * x^{2} ; R^{2}=0.621$ $\bullet$ Phi $\hat{y}=\bar{y}=39.7$

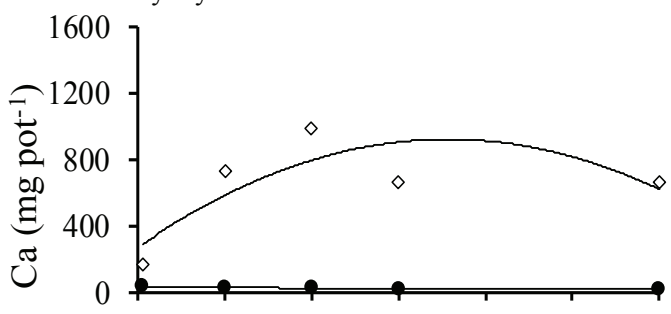

(e) $\quad$ Pi $\hat{y}=10.243+1.091 * x-0.0151 * x^{2} ; R^{2}=0.621$

$\bullet P h i \hat{y}=4.8532-0.0524 * * x ; R^{2}=0.534$

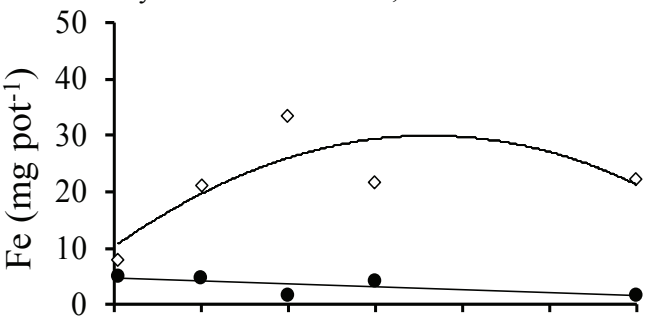

(g) $\quad$ Pi $\hat{y}=1.0861+0.0607 x-0.0009 * x^{2} \quad R^{2}=$ 0.5449

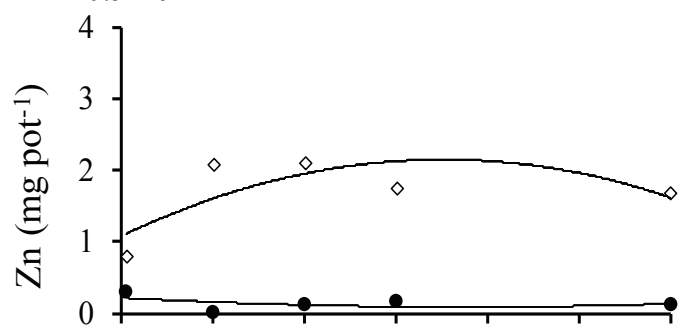

(i) $\diamond \mathrm{Pi} \hat{\mathrm{y}}=44.001-11.44 * * \ln (\mathrm{x}) ; \mathrm{R}^{2}=0.931$

(i) $\bullet$ Phi $\hat{y}=16.252-3.865 * * \ln (\mathrm{x}) ; \quad \mathrm{R}^{2}=0.903$

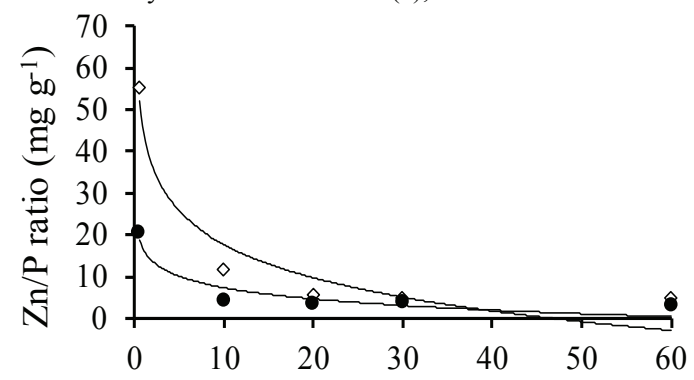

(b) $\diamond$ Pi $\hat{y}=423.270+36.253^{* *} \mathrm{x}-0.4898^{* *} \mathrm{x}^{2} ; \mathrm{R}^{2}=0.755$ $\bullet$ Phi $\hat{y}=85.022-0.5762 * x ; R^{2}=0.693$

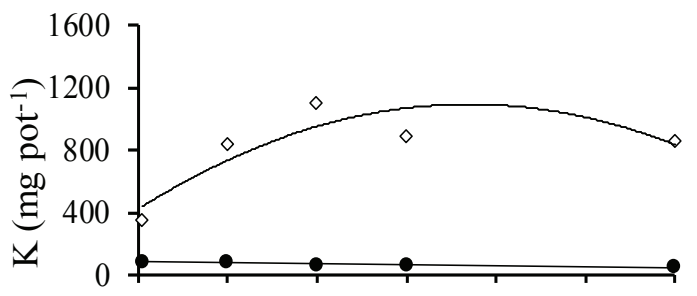

(d) $\quad \diamond \mathrm{Pi} \hat{\mathrm{y}}=31.847+3.7918^{* *} \mathrm{x}-0.0518^{* *} \mathrm{x}^{2} ; \mathrm{R}^{2}=0.760$ $\bullet$ Phi $\hat{y}=\bar{y}=8.201$

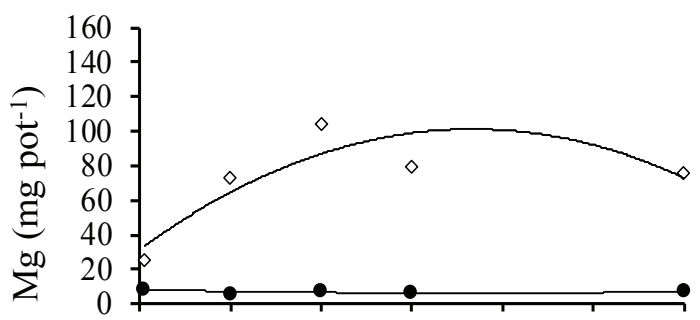

$\quad$ (f) $\quad \hat{y}=3.0753+0.2218 * x-0.0032 * x^{2} R^{2}=0.540$
$\bullet P h i \hat{y}=\bar{y}=0.5881$

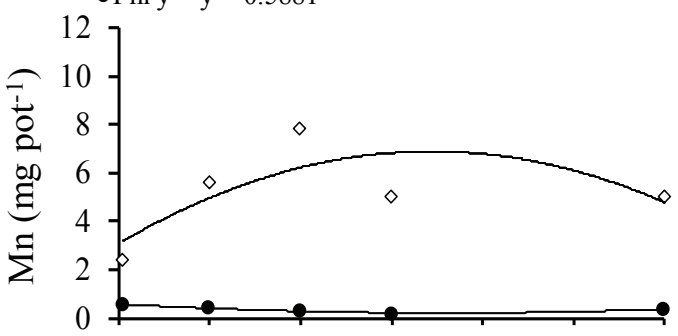

$\diamond \mathrm{Pi} \hat{y}=0.112+0.0153 * * x-0.0002 * \mathrm{x}^{2} ; \mathrm{R}^{2}=0.781$

(h) $\bullet$ Phi $\hat{y}=\bar{y}=0.07$

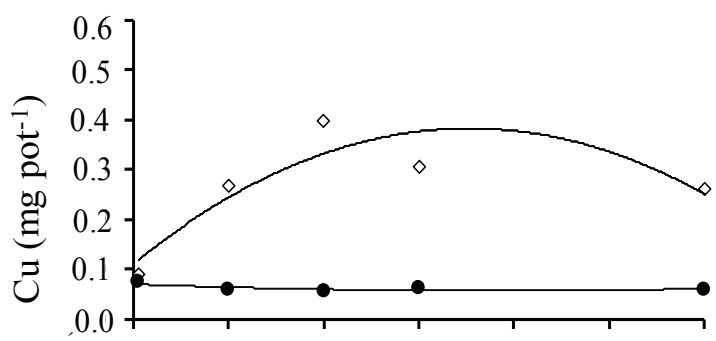

(i) $\diamond \mathrm{Pi} \hat{\mathrm{y}}=47.208-12.11^{* *} \ln (\mathrm{x}) ; \mathrm{R}^{2}=0.964$

$\bullet$ Phi $\hat{y}=20.752-4.885^{* *} \ln (x) ; R^{2}=0.905$

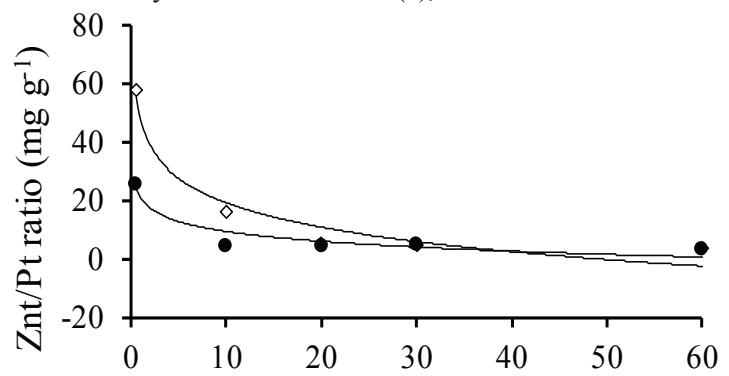

Concentrations of phosphorus (mg L-1)

Figure 2. Accumulation of macro and micronutrients and zinc/phosphorus ratio in common bean grown in nutrient solution under concentrations of phosphate $(\mathrm{Pi})$ and phosphite (Phi). ** and *: significant at $1 \%$ and $5 \%$ by the $\mathrm{F}$ test, respectively. 
to the phytotoxicity caused by the application of phosphite as the sole source of $\mathrm{P}$ for bean plants. This resulted in a lower growth of shoots and roots (Araujo 2008). Araújo et al. (2013 and 2014) found a decrease in the growth of the shoot and root system of common bean, when phosphite was provided in the absence of phosphate, or when phosphite ratios were higher than $25 \%$ of the phosphorus supplied to the crop, or even when phosphite was provided via leaves to bean plants grown with a low availability of $\mathrm{P}$. This explains the sharp decrease in the nutrient accumulation obtained in this study, provided by the supply of $\mathrm{P}$ as phosphite.

Differently from what happened with the application of phosphite, when $\mathrm{P}$ was provided in the form of phosphate, there was a quadratic fit for the accumulation of all analyzed nutrients, as a function of $\mathrm{P}$ concentrations in the nutrient solution (Figure 2). The maximum value of $\mathrm{P}$ accumulation (Figure $2 \mathrm{a}$ ) occurred at $48.8 \mathrm{mg} \mathrm{L}^{-1}$ of $\mathrm{P}$ in the form of phosphate, in the nutrient solution. For the other nutrients, the highest values were obtained with concentrations ranging from $33.7 \mathrm{mg} \mathrm{L}^{-1}$ (accumulation values for $\mathrm{Zn}$ ) to $38.3 \mathrm{mg} \mathrm{L}^{-1}$ (accumulation values for $\mathrm{Cu}$ ). This was also observed in other studies (Wissuwa et al. 2005, Ávila et al. 2013) and is due to the role of phosphorus in the plant metabolism, such as energy transfer and cell division, which is directly related to the growth and accumulation of nutrients by the plant (Clarkson 1985).

The Zn/P (Figure 2i) and Znt/Pt (Figure 2j) ratios decreased exponentially with the increase in the $\mathrm{P}$ concentration of the solution. When $\mathrm{P}$ was provided as phosphite, there was a sharp decrease in the $\mathrm{Zn} / \mathrm{P}$ and $\mathrm{Znt} / \mathrm{Pt}$ ratios, as a function of $\mathrm{P}$ concentrations in the nutrient solution. According to Mousavi (2011) and Mai (2011), the decrease in the $\mathrm{Zn} / \mathrm{P}$ ratio may occur because of a decreased absorption and translocation of $\mathrm{Zn}$, due to the high $\mathrm{P}$ concentration in the growth medium, possibly due to precipitation of poorly soluble forms of $\mathrm{Zn}^{2+}$ with phosphate ions, which occur both externally and internally to root tissues. In addition, it can also be a consequence of the "dilution effect" caused by the higher production of dry mass in response to a proper availability of $\mathrm{P}$ in the growth medium, as observed for common bean by Ávila et al. (2013). However, when the form of $P$ was Phi, the dilution effect did not happen, because there was a decrease in growth with the increase in the concentrations of this anion (Araújo et al. 2013).
Translocation rates of nutrients to the plant shoot, as a function of $\mathrm{P}$ concentrations in the solution, responded variably depending on the nutrient evaluated and the form of $P$ provided (Figure 3). The application of $\mathrm{P}$ as phosphite promoted the highest translocation of P (Figure 3a), indicating that this anion is possibly more mobile than the phosphate anion in plants. This increased mobility of phosphite, in relation to phosphate, may be because phosphite has one less atom of oxygen in its molecular structure (White \& Metcalf 2007), what presumably facilitates its movement in the xylem and phloem vessels. However, there are no studies proving this.

For the nutrients K (Figure 3b), Ca (Figure 3c) and $\mathrm{Mn}$ (Figure 3f), there was a quadratic fit for the concentrations of $\mathrm{P}$, independently of the form applied. For Zn (Figure 3g) and Cu (Figure 3h), translocation was not influenced by $\mathrm{P}$ concentration and form applied. This indicates that $\mathrm{P}$ interacts positively with $\mathrm{Ca}, \mathrm{K}$ and $\mathrm{Mn}$, facilitating their translocation to plant shoots. This does not occur with $\mathrm{Zn}$ and $\mathrm{Cu}$, and explanations for this fact were not found in the literature. The translocation of $\mathrm{Mg}$ and mainly of Fe decreased with the application of phosphite. One of the symptoms of phytotoxicity by phosphite in bean plants is internerval chlorosis, with a fine reticulation in young leaves, similar to Fe deficiency, accompanied by a "shriveling" in the shape of a canoe (Araujo 2008). Possibly, phosphite anions have higher affinity to $\mathrm{Fe}^{2+}$ than phosphate anions, forming insoluble complexes with $\mathrm{Fe}^{2+}$ on the root surface, reducing its accumulation and translocation to shoots. Although no reports of this effect were found in the literature, there was formation of iron precipitates in the bottom of the pots in which phosphite was the only form of $\mathrm{P}$ and in those in which this anion was in proportions above $50 \%$. This precipitation of iron in the presence of phosphite confirms that hypothesis.

The phosphite ratios significantly influenced all the studied variables. It was observed that the accumulated quantities and the translocation of $\mathrm{P}$ and cationic nutrients were negatively affected by increased proportions of phosphite, in relation to phosphate, in the nutrient solution (Figures 4 and 5). There was a decrease in the accumulated contents (Figure 4) of all nutrients evaluated with increasing proportions of phosphite, which were practically zero when phosphite was the sole form of phosphorus. For phosphorus (Figure 4a), the decrease was linear, 
while, for the other nutrients, the effect was quadratic. The maximum values were obtained with phosphite proportions (Phi) ranging from $6.9 \%$ (Fe) to $26.3 \%$ $(\mathrm{Mn})$. These results show that it is not possible to completely replace phosphate by phosphite in the nutrient solution, but that concentrations of P-Phi between $1.7 \mathrm{mg} \mathrm{L}^{-1}$ and $6.3 \mathrm{mg} \mathrm{L}^{-1}$ may increase the absorption of certain nutrients, provided that the plant is supplied with phosphate concentrations between $22.3 \mathrm{mg} \mathrm{L}^{-1}$ and $17.7 \mathrm{mg} \mathrm{L}^{-1}$, respectively.

The decrease in the accumulation of nutrients observed for larger Phi proportions in the solution is due to a lower production of dry matter, possibly caused by a decrease in the PI absorption rate by the root system, due to a competitive inhibition of phosphate by phosphite (Ávila et al. 2011). Furthermore, P-Phi (a) $\diamond \mathrm{Pi} \hat{y}=75.999-0.2375^{*} \mathrm{x} ; \mathrm{R}^{2}=0.442$

(a) •Phi $\hat{y}=81.161+0.7588^{* *} \mathrm{x}-0.009^{* *} \mathrm{x}^{2} \quad \mathrm{R}^{2}=0.824$

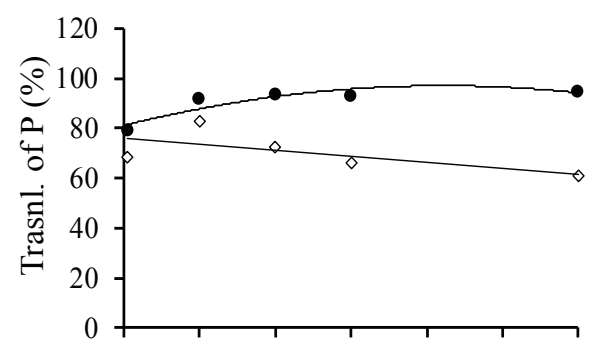

(c)

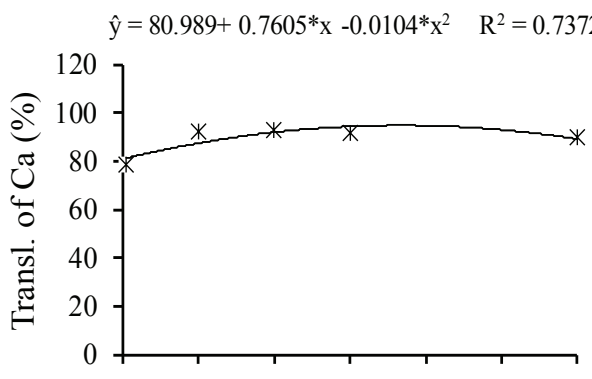

(e) $\quad \diamond \mathrm{Pi} \hat{y}=26.58+2,0404^{*} \mathrm{x}-0.0286^{*} \mathrm{x}^{2} \mathrm{R}^{2}=0.582$ $\bullet$ Phi $\hat{y}=\bar{y}=10.624$
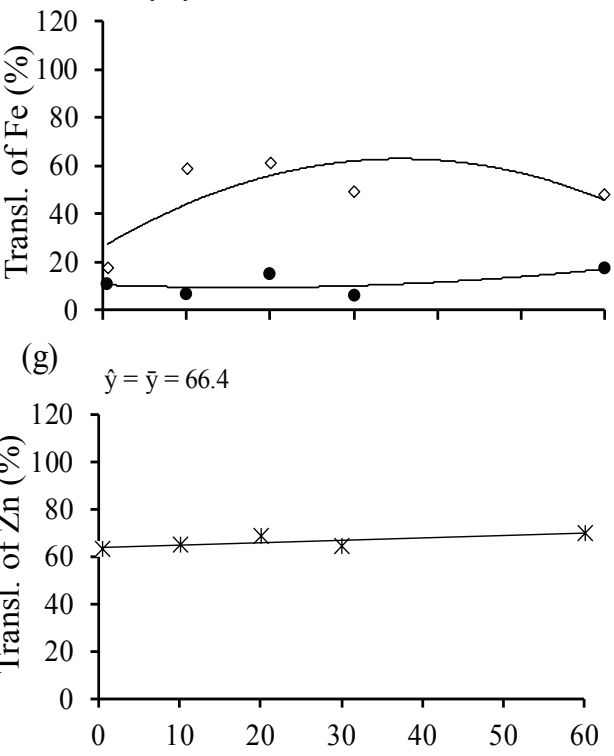

(b) $\hat{y}=63.87+1.2704 * x-0.016 * x^{2} \quad R^{2}=0.7601$

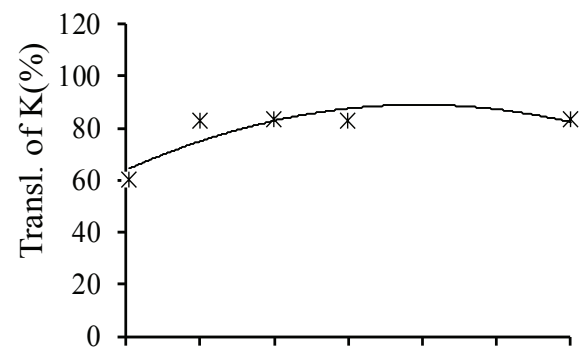

(d)

$\diamond \mathrm{Pi} \hat{y}=54.917+0.7673^{*} x-0.0096^{*} x^{2} \quad R^{2}=0.461$ $\bullet$ Phi $\hat{y}=\bar{y}=56.803$

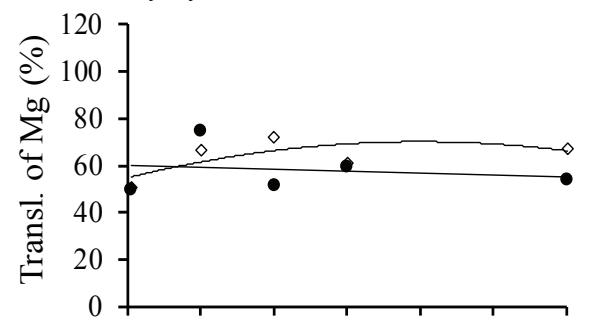

(f) $\hat{\mathrm{y}}=41.969+2.5857^{*} \mathrm{x}-0.047^{* *} \mathrm{x}^{2} \quad \mathrm{R}^{2}=0.864$

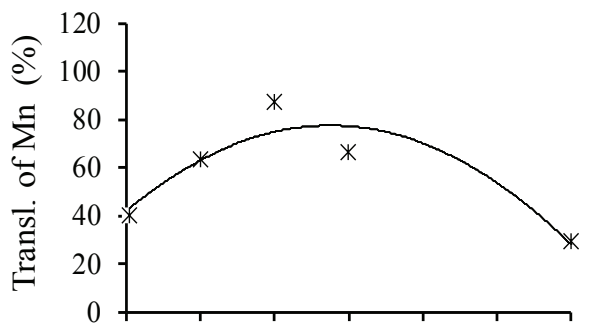

(h)

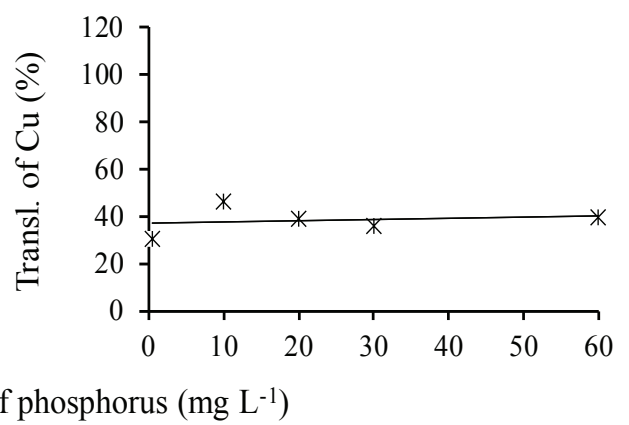

Figure 3. Translocation (Transl.) of macro and micronutrients in common bean grown in nutrient solution under concentrations of phosphate $(\mathrm{Pi})$ and phosphite (Phi). $* *$ and $*$ : significant at $1 \%$ and $5 \%$ by the $\mathrm{F}$ test, respectively. 

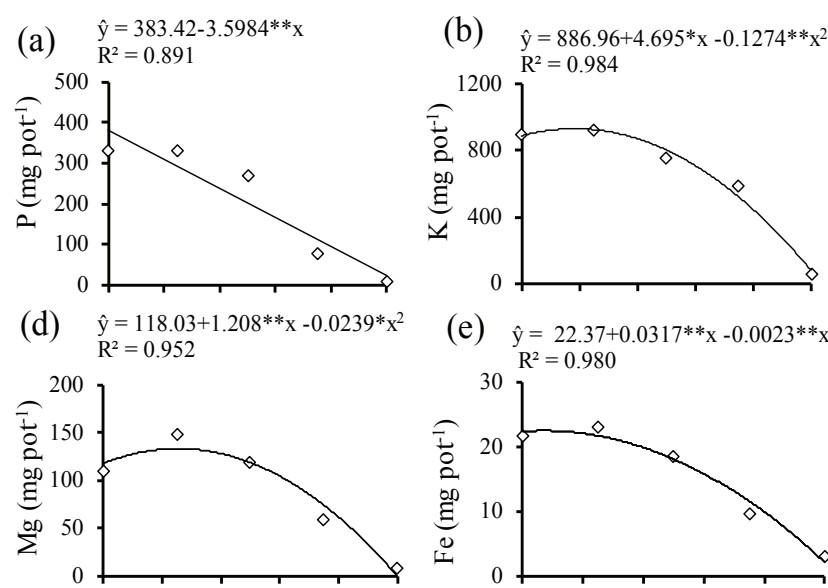

(e) $\hat{\mathrm{y}}=22.37+0.0317^{* *} \mathrm{x}-0.0023 * * \mathrm{x}^{2}$
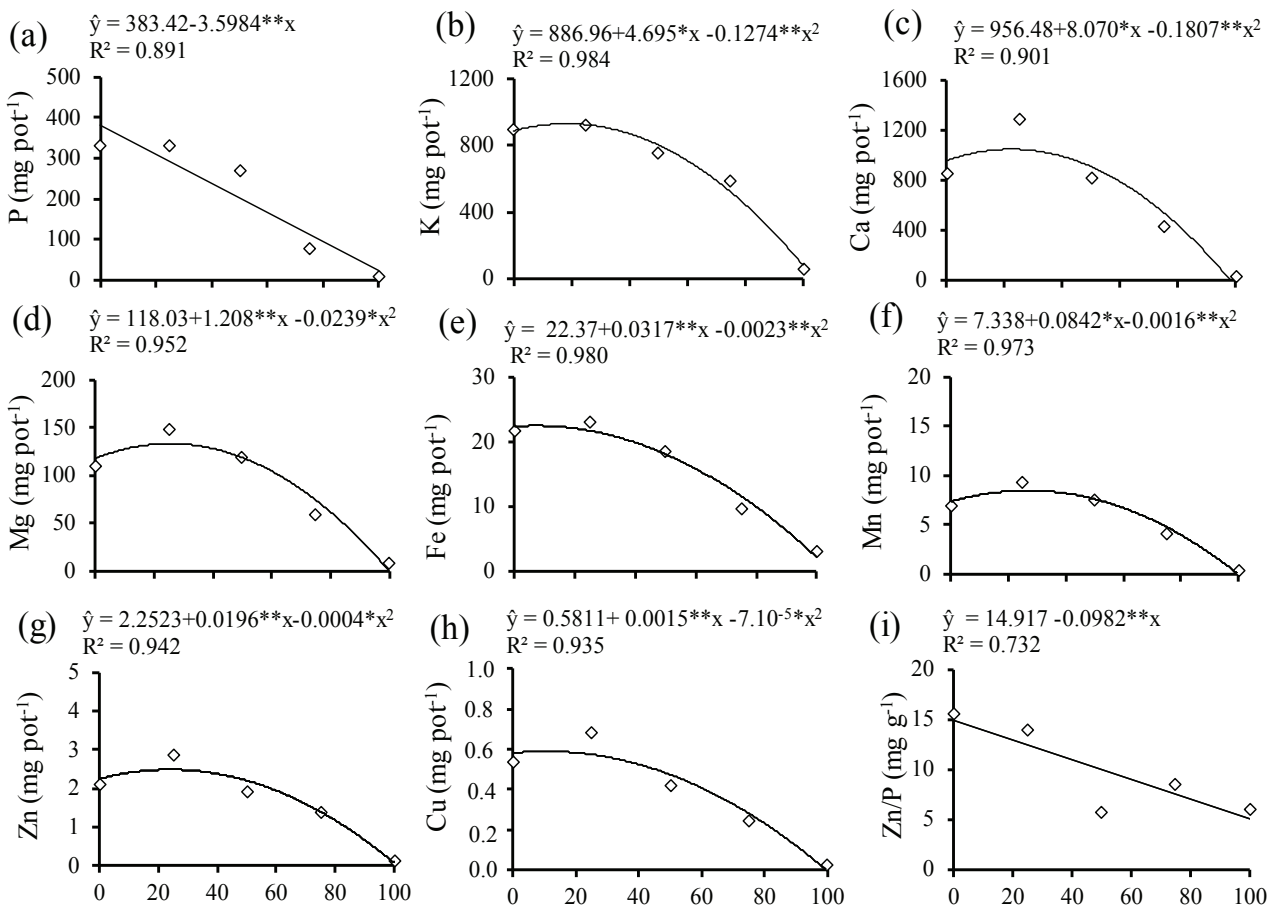

Phosphite $(\%)$

Figure 4. Accumulation of macro and micronutrients in common bean grown in nutrient solution under proportions of phosphite (Phi). ** and *: significant at $1 \%$ and $5 \%$ by the $\mathrm{F}$ test, respectively.
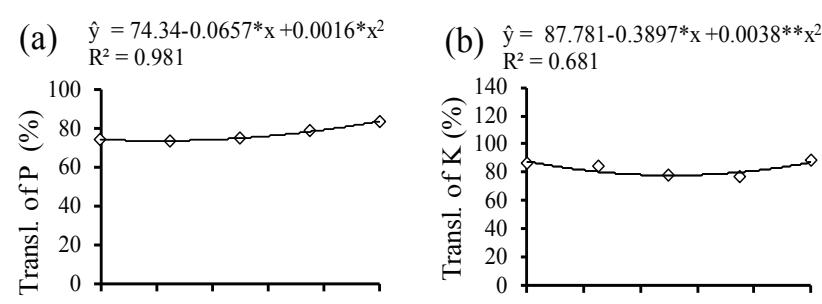

(c) $\hat{\mathrm{y}}=90.56-0.1017^{* *} \mathrm{x}$
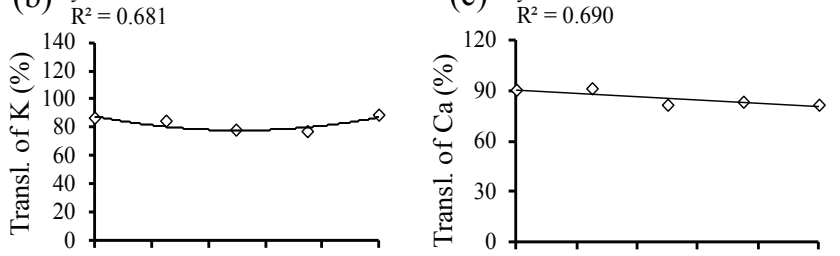

(d) $\hat{y}=\bar{y}=54.726$

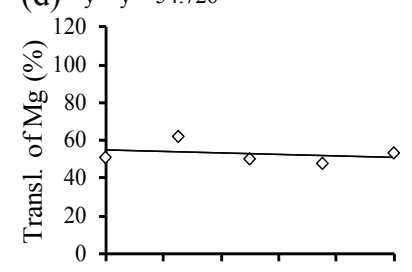

(e) $\hat{\mathrm{y}}=59.91+0,8378 * * \mathrm{x}-0.0128 * \mathrm{x}^{2}$

(f) $\hat{\mathrm{y}}=-0.2647 * * \mathrm{x}+65.41$

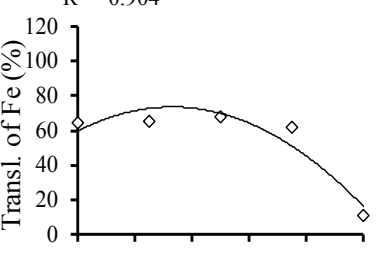

(g) $\hat{y}=\bar{y}=75.868$

(h) $\hat{y}=72.084-0.1649 * * x R^{2}=0.591$
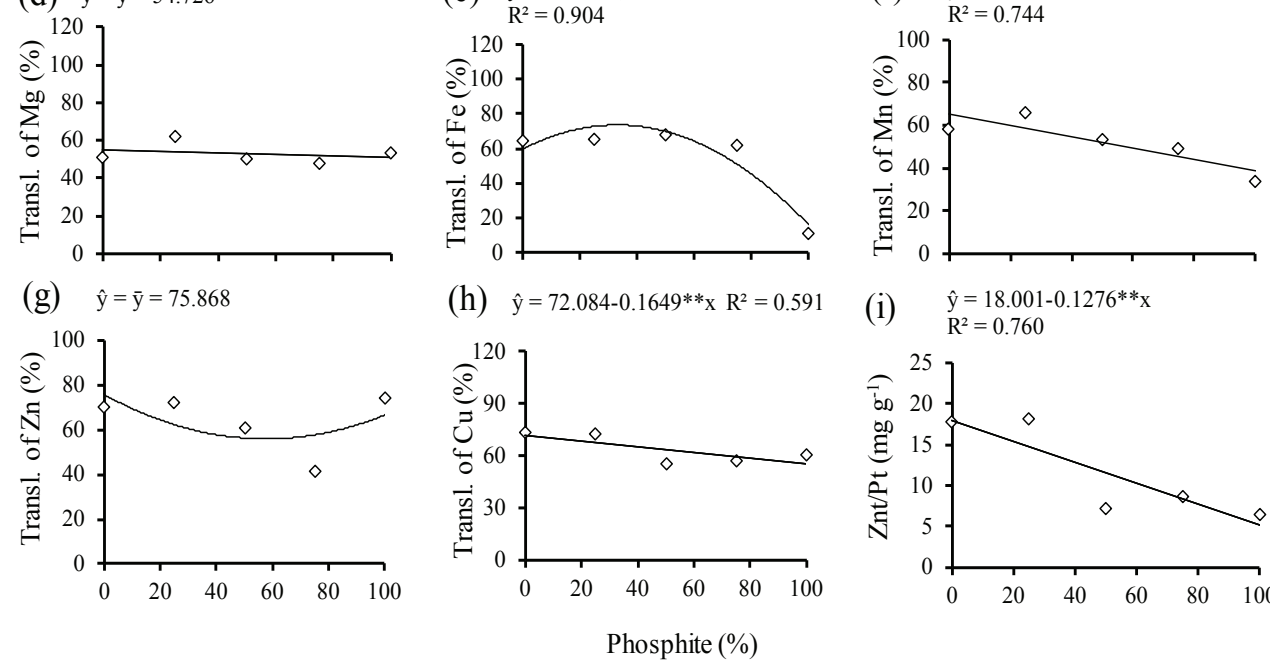

(i) $\begin{aligned} & \hat{y}=18.001-0.1276 * * \mathrm{x} \\ & \mathrm{R}^{2}=0.760\end{aligned}$

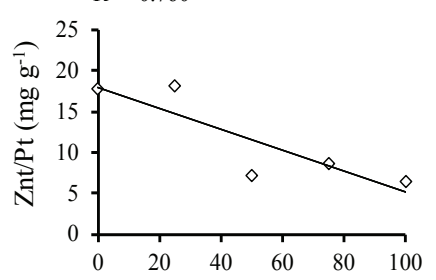

Figure 5. Translocation (Transl.) of macro and micronutrients and Znt/Pt ratio in common bean grown in nutrient solution with varying proportions of phosphate $(\mathrm{Pi})$ and phosphite $(\mathrm{Phi}){ }^{* *}$ and $*$ : significant at $1 \%$ and $5 \%$ by the $\mathrm{F}$ test, respectively. $\mathrm{Znt} / \mathrm{Pt}$ : ratio between total zinc accumulation and total phosphorus accumulation in the whole plant. 
proportions higher than $25 \%$ in the solution were toxic to bean plants, as demonstrated visually by the shortening and thickening of roots and by the chlorosis in young leaves, as also observed for other crops (Varadarajan et al. 2002, Thao \& Yamakawa 2009). This results in a lower production of dry matter (Araújo et al. 2013), which explains the lower accumulation of nutrients. The $\mathrm{Zn} / \mathrm{P}$ ratio in shoots also decreased linearly according to Phi ratios in the solution. This indicates a negative interference of phosphite in the absorption and translocation of $\mathrm{Zn}$ in bean, as observed in the first experiment (Figures $2 \mathrm{i}$ and $2 \mathrm{j}$ ).

The translocation of $\mathrm{P}$ (Figure $5 \mathrm{a}$ ) and $\mathrm{K}$ (Figure 5b), although moderately, tended to increase with the increase in phosphite proportions. This was also observed for $\mathrm{P}$ in the previous experiment (Figure 3a), where phosphite favored the translocation of $\mathrm{P}$. On the other hand, there were decreases in the translocations of $\mathrm{Ca}, \mathrm{Fe}, \mathrm{Mn}, \mathrm{Cu}$ and especially $\mathrm{Fe}$, which, with $100 \%$ of Phi, had its translocation almost ceased. As pointed before, higher proportions of phosphite cause the precipitation of $\mathrm{Fe}$ in the nutrient solution. For the other nutrients, however, no explanations for this effect were found in the literature. It is possible that this decrease occurred due to the depressing effects of phosphite on plant roots, reducing its absorption and hence its transport to shoots, or due to a phosphate precipitation process of these nutrients in roots.

There was interaction between the factors $\mathrm{P}$ concentration in the solution and foliar application treatments for the $\mathrm{P}$ accumulated in tissues and its translocation from roots to shoots, as well as for $\mathrm{Zn} / \mathrm{P}$ and $\mathrm{Znt} / \mathrm{Pt}$ ratios (Table 1). For other nutrients, there was an effect of factors only in isolation (Table 2). Under appropriate supply of $\mathrm{P}$ in the hydroponic solution, Phi provided an accumulation of $\mathrm{P}$ in beans similar to the treatment with $\mathrm{KCl}$. Pi possibly stimulated plant growth and hence increased the accumulation of P. Under P deficiency $\left(1.5 \mathrm{mg} \mathrm{L}^{-1}\right)$,

Table 1. Phosphorus accumulation and translocation and $\mathrm{Zn} / \mathrm{P}$ ratio in common bean under foliar application treatments (Phi, Pi and $\mathrm{KCl})$ and phosphate $(\mathrm{Pi})$ concentrations in the nutrient solution [low $\left(1.5 \mathrm{mg} \mathrm{L}^{-1}\right)$ and adequate $\left.\left(20 \mathrm{mg} \mathrm{L}^{-1}\right)\right]$.

\begin{tabular}{|c|c|c|c|c|c|c|c|c|}
\hline \multirow{3}{*}{ Treatment } & \multicolumn{2}{|c|}{ Accumulated P } & \multicolumn{2}{|c|}{ Translocated P } & \multirow{2}{*}{\multicolumn{2}{|c|}{ Shoot $\mathrm{Zn} / \mathrm{P}$ ratio }} & \multirow{2}{*}{\multicolumn{2}{|c|}{$\mathrm{Znt} / \mathrm{Pt}$}} \\
\hline & $1.5 \mathrm{mg} \mathrm{L}^{-1}$ & $20 \mathrm{mg} \mathrm{L}^{-1}$ & $1,5 \mathrm{mg} \mathrm{L}^{-1}$ & $20 \mathrm{mg} \mathrm{L}^{-1}$ & & & & \\
\hline & \multicolumn{2}{|c|}{$\mathrm{mg} \mathrm{pot}^{-1}$} & \multicolumn{2}{|c|}{$\%$} & \multicolumn{4}{|c|}{$\mathrm{mg} \mathrm{g}^{-1}$} \\
\hline Phi & $30.3 \mathrm{aB}$ & $254.8 \mathrm{bA}$ & $86.0 \mathrm{aA}$ & $83.8 \mathrm{aA}$ & $21.1 \mathrm{c} \mathrm{A}$ & $6.06 \mathrm{aB}$ & $25.2 \mathrm{bA}$ & $5.9 \mathrm{aB}$ \\
\hline $\mathrm{Pi}$ & $32.9 \mathrm{aB}$ & $308.2 \mathrm{aA}$ & $72.8 \mathrm{bA}$ & $85.9 \mathrm{aA}$ & $25.6 \mathrm{bA}$ & $5.69 \mathrm{aB}$ & $27.4 \mathrm{bA}$ & $6.1 \mathrm{aB}$ \\
\hline $\mathrm{KCl}$ & $27.3 \mathrm{aB}$ & $294.9 \mathrm{bA}$ & $72.9 \mathrm{bB}$ & $85.1 \mathrm{aA}$ & $37.2 \mathrm{aA}$ & $6.05 \mathrm{aB}$ & $36.9 \mathrm{aA}$ & $6.1 \mathrm{aB}$ \\
\hline
\end{tabular}

Means followed by the same lower case letter, in the column, and capital case, in the row, do not differ by the Tukey test ( $\mathrm{p}<0.05)$. Znt/Pt: ratio between total zinc and total phosphorus accumulation in the whole plant. $\mathrm{Phi}, \mathrm{Pi}$ and $\mathrm{KCl}: 40 \mathrm{mmol} \mathrm{L}{ }^{-1}$ of $\mathrm{KH}_{2} \mathrm{PO}_{3}, \mathrm{KH}_{2} \mathrm{PO}_{4}$ and $\mathrm{KCl}$, respectively.

Table 2. Accumulation and translocation of cationic nutrient in common bean under phosphate (Pi) concentrations in the nutrient solution [low $\left(1.5 \mathrm{mg} \mathrm{L}^{-1}\right)$ and adequate $\left(20 \mathrm{mg} \mathrm{L}^{-1}\right)$ ].

\begin{tabular}{|c|c|c|c|c|c|c|c|}
\hline Treatment & $\mathrm{K}$ & $\mathrm{Ca}$ & $\mathrm{Mg}$ & $\mathrm{Fe}$ & $\mathrm{Mn}$ & $\mathrm{Zn}$ & $\mathrm{Cu}$ \\
\hline & \multicolumn{7}{|c|}{ Accumulation $\left(m g\right.$ pot $\left.^{-1}\right)$} \\
\hline $1.5 \mathrm{mg} \mathrm{L}^{-1}$ of $\mathrm{P}$ & $456.0 \mathrm{~b}$ & $384.0 \mathrm{~b}$ & $45.0 \mathrm{~b}$ & $16.0 \mathrm{~b}$ & $4.0 \mathrm{~b}$ & $0.9 \mathrm{~b}$ & $0.39 \mathrm{~b}$ \\
\hline \multirow[t]{2}{*}{$20 \mathrm{mg} \mathrm{L} \mathrm{L}^{-1}$ of P } & $913.0 \mathrm{a}$ & $1,162.0 \mathrm{a}$ & $167.0 \mathrm{a}$ & $21.0 \mathrm{a}$ & $5.6 \mathrm{a}$ & $1.7 \mathrm{a}$ & $0.75 \mathrm{a}$ \\
\hline & \multicolumn{7}{|c|}{ Translocation (\%) } \\
\hline $1.5 \mathrm{mg} \mathrm{L}^{-1}$ of $\mathrm{P}$ & $76.1 \mathrm{~b}$ & $89.9 \mathrm{~b}$ & $64.0 \mathrm{a}$ & $11.6 \mathrm{~b}$ & $26.3 \mathrm{~b}$ & $71.4 \mathrm{~b}$ & $76.3 \mathrm{~b}$ \\
\hline \multirow[t]{2}{*}{$20 \mathrm{mg} \mathrm{L}^{-1}$ of $\mathrm{P}$} & $86.3 \mathrm{a}$ & $95.7 \mathrm{a}$ & $57.6 \mathrm{a}$ & $26.5 \mathrm{a}$ & $53.9 \mathrm{a}$ & $83.6 \mathrm{a}$ & $85.1 \mathrm{a}$ \\
\hline & \multicolumn{7}{|c|}{ Accumulation $\left(\mathrm{mg} \mathrm{pot}^{-1}\right)$} \\
\hline Phi & $586.9 \mathrm{~b}$ & $612.2 \mathrm{~b}$ & $92.6 \mathrm{~b}$ & $15.6 \mathrm{~b}$ & $4.2 \mathrm{~b}$ & $1.2 \mathrm{a}$ & $0.49 \mathrm{a}$ \\
\hline $\mathrm{Pi}$ & $752.2 \mathrm{a}$ & $873.1 \mathrm{a}$ & $113.2 \mathrm{a}$ & $20.2 \mathrm{a}$ & $5.4 \mathrm{a}$ & $1.3 \mathrm{a}$ & $0.57 \mathrm{ab}$ \\
\hline \multirow[t]{2}{*}{$\mathrm{KCl}$} & $714.8 \mathrm{ab}$ & $835.7 \mathrm{a}$ & $113.7 \mathrm{a}$ & $20.4 \mathrm{a}$ & $4.8 \mathrm{ab}$ & $1.4 \mathrm{a}$ & $0.65 \mathrm{a}$ \\
\hline & \multicolumn{7}{|c|}{ Translocation (\%) } \\
\hline Phi & $83.5 \mathrm{a}$ & $92.7 \mathrm{a}$ & $63.1 \mathrm{a}$ & $19.2 \mathrm{a}$ & $44.3 \mathrm{a}$ & $77.6 \mathrm{a}$ & $78.7 \mathrm{a}$ \\
\hline $\mathrm{Pi}$ & $80.6 \mathrm{a}$ & $93.2 \mathrm{a}$ & $60.9 \mathrm{a}$ & $19.6 \mathrm{a}$ & $36.2 \mathrm{a}$ & $75.8 \mathrm{a}$ & $84.0 \mathrm{a}$ \\
\hline $\mathrm{KCl}$ & $79.6 \mathrm{a}$ & $92.4 \mathrm{a}$ & $58.4 \mathrm{a}$ & $18.3 \mathrm{a}$ & $34.8 \mathrm{a}$ & $78.9 \mathrm{a}$ & $79.4 \mathrm{a}$ \\
\hline
\end{tabular}

Means followed by the same letter, in the column, comparing concentrations of $\mathrm{P}$ or the product applied (Phi, Pi and $\mathrm{KCl})$, do not differ by the Tukey test ( $<<0.05)$. Phi, $\mathrm{Pi}$ and $\mathrm{KCl}: 40 \mathrm{mmol} \mathrm{L}^{-1}$ of $\mathrm{KH}_{2} \mathrm{PO}_{3}, \mathrm{KH}_{2} \mathrm{PO}_{4}$ and $\mathrm{KCl}$, respectively. 
there were no differences among foliar application products (Table 1). In turn, when the level of $\mathrm{P}$ in the solution was deficient, the translocation of $\mathrm{P}$ in bean plants was greater with a foliar application of Phi. This may be a consequence of the negative effect of phosphite on the root system of the plant, reducing the accumulation of $\mathrm{P}$ in roots and accumulating a greater amount in shoots, due to its foliar application. However, when the P level of the solution was adequate, the translocation of $\mathrm{P}$ was not affected by foliar application treatments. The $\mathrm{Zn} / \mathrm{P}$ and $\mathrm{Znt} / \mathrm{Pt}$ ratios were lower with the foliar application of $\mathrm{Phi}$ or Pi in plants grown in a nutrient solution deficient in $\mathrm{P}\left(1.5 \mathrm{mg} \mathrm{L}^{-1}\right)$, similarly to the first and second experiments.

Due to the lack of $\mathrm{P}$, there was a lower translocation and a decreased accumulation of all analyzed nutrients (Table 2), as a result of the combined effect of the less absorbed quantity of these nutrients and of the decreased dry matter production, in view of the important role of $\mathrm{P}$ on the development of the root system (Wissuwa et al. 2005). The lower translocation of nutrients to shoots in P-deficient plants is probably due to an increased root production over the production of dry matter (Araújo et al. 2014), as a mechanism to overcome this deficiency (Clarkson 1985). In this sense, the micronutrients $\mathrm{Fe}$ and $\mathrm{Mn}$ had proportionally most of its translocation hindered due to the lack of P. Similarly to the first experiment, except for $\mathrm{Zn}$, Phi provided via leaf also decreased the accumulation of cationic nutrients in bean plants (Table 2). However, similarly to the results of the first experiment, except for Fe (Figure 3e), the translocation of these nutrients was not affected by this anion.

The results from the three experiments indicate that phosphites should not be applied via roots or leaves, as a way to overcome occasional phosphorus deficiencies. This is because this anion, in this situation, besides not meeting the needs of the plant, could also be toxic. However, it should be noted that this study was conducted in a nutrient solution, where the P-Phi ratio is not subjected to phosphate oxidation or to adsorption processes that may occur in the soil (White \& Metcalf 2007).

\section{CONCLUSIONS}

1. Under phosphate deficiency, phosphite applied via nutrient solution to the roots decreases the accumulation of phosphorus and cationic nutrients in bean plants. P-Phi decreases the $\mathrm{Zn} / \mathrm{P}$ ratio, increases the translocation of $\mathrm{P}$ and decreases the translocation of $\mathrm{Fe}$;

2. The application of P-Phi to leaves do not affect the phosphorus nutrition of bean plants or the translocation of nutrients. However, it decreases the accumulation of $\mathrm{K}, \mathrm{Ca}, \mathrm{Mg}, \mathrm{Fe}$ and $\mathrm{Mn}$. The application of P-Pi to leaves, under adequate $\mathrm{P}$ supply in the nutrient solution, increases the accumulation of this nutrient in the plant.

\section{REFERENCES}

ARAUJO, J. L. Crescimento e nutrição fosfatada do feijoeiro em função da aplicação via radicular e foliar de fosfito. 77 f. 2008. Tese (Doutorado em Ciência do Solo) Universidade Federal de Lavras, Lavras, 2008.

ARAÚJO, J. L. et al. Crescimento e acúmulo de fósforo pelo feijoeiro tratado com fosfato e fosfito via foliar. Semina: Ciências Agrárias, v. 35, n. 4, p. 1425-1437, 2014.

ARAÚJO, J. L. et al. Interação fosfito e fosfato no crescimento e na nutrição fosfatada do feijoeiro em solução nutritiva. Revista Brasileira de Ciência do Solo, v. 37, n. 2, p. 482-490, 2013.

ÁVILA, F. W. et al. Effect of phosphite supply in nutrient solution on yield, phosphorus nutrition and enzymatic behavior in common bean (Phaseolus vulgaris L.) plants. Australian Journal of Crop Science, v. 7, n. 5, p. 713-722, 2013.

ÁVILA, F. W. et al. Growth, phosphorus status, and nutritional aspect in common bean exposed to different soil phosphate levels and foliar-applied phosphorus forms. Scientific Research and Essays, v. 7, n. 25, p. 2195-2204, 2012.

ÁVILA, F. W. et al. Phosphite supply affects phosphorus nutrition and biochemical responses in maize plants. Australian Journal of Crop Science, v. 5, n. 5, p. 646-653, 2011.

BERTSCH, F.; RAMÍREZ, F.; HENRÍQUEZ, C. Evaluación del fosfito como fuente fertilizante de fósforo vía radical y foliar. Agronomia Costarricense, v. 33, n. 2, p. 249-265, 2009.

CLARKSON, D. T. Factors affecting mineral nutrient acquisition by plants. Annual Review of Plant Physiology, v. 36, n. 1, p. 77-115, 1985.

ESTRADA-ORTIZ, E. et al. The effects of phosphite on strawberry yield and fruit quality. Journal of Soil Science and Plant Nutrition, v. 13, n. 3, p. 612-620, 2013.

GÓMEZ-MERINO, F. C.; TREJO-TÉLLEZ, L. T. Biostimulant activity of phosphite in horticultue. Scientia Horticulturae, v. 196, n. 1, p. 82-90, 2015. 
MAI, W. X. Tolerance to Zn deficiency and P-Zn interaction in wheat seedlings cultured in chelator-buffered solutions. Journal of Arid Land, v. 3, n. 3, p. 206-213, 2011.

MALAVOLTA, E.; VITTI, G. C.; OLIVEIRA, S. A. Avaliação do estado nutricional das plantas: princípios e aplicações. 2. ed. Piracicaba: Associação Brasileira para Pesquisa da Potassa e do Fosfato, 1997.

MOOR, U. et al. Effect of phosphite fertilization on growth, yield and fruit composition. Scientiae Horticulturae, v. 119, n. 3, p. 264-269, 2009.

MOUSAVI, R. S. Zinc in crop production and interaction with phosphorus. Australian Journal of Basic and Applied Science, v. 9, n. 3, p. 1503-1509, 2011.

ORBOVIĆ, V. et al. Citrus seedling growth and susceptibility to root rot as affected by phosphite and phosphate. Journal of Plant Nutrition, v. 31, n. 4, p. 774-787, 2008.

RICKARD, D. A. Review of phosphorus acid and its salts as fertilizer materials. Journal of Plant Nutrition, v. 23, n. 2, p. 61-180, 2000.

SCHRÖETTER, S. Effects of phosphite on phosphorus supply and growth of corn (Zea mays). Landbauforschung
Volkenrodxe, Fal Agricultural Research, v. 56, n. 3/4, p. 87-99, 2006.

TAMBASCIO, C. et al. The application of $\mathrm{K}$ phosphites to seed tubers enhanced emergence, early growth and mycorrhizal colonization in potato (Solanum tuberosum). American Journal of Plant Science, v. 5, n. 1, p. 132-137, 2014.

THAO, H. T. B.; YAMAKAWA, T. Phosphite (phosphorus acid): fungicide, fertilizer or bio-stimulator? Soil Science and Plant Nutrition, v. 55, n. 2, p. 228-234, 2009.

VARADARAJAN, D. K. et al. Phosphite, an analog of phosphate suppresses the coordinated expression of genes under phosphate starvation. Plant Physiology, v. 129, n. 3, p. 1-9, 2002.

WHITE, A. K.; METCALF, W. W. Microbial metabolism of reduced phosphorus compounds. Annual Review of Microbiology, v. 61, n. 1, p. 379-400, 2007.

WISSUWA, M.; GAMAT, G.; SMAIL, A. M. Is root growth under phosphorus deficiency affected by source or sink limitations? Journal of Experimental Botany, v. 56, n. 417, p. 1943-1950, 2005. 